\title{
A Critical Study on (IPM) Integrated Pest Management and its Adoption among the Soybean Growing Farmers of Khandwa District of M.P, India
}

\author{
Shivpal Singh ${ }^{1 *}$, G. Bihare ${ }^{2}$, P. Kumar ${ }^{1}$, G. Uikey ${ }^{2}$ and K. Agrawals ${ }^{3}$ \\ ${ }^{1}$ Department of Agriculture Extension Education, \\ Jawaharlal Nehru Krishi Krishi Vishwa Vidyalaya Jabalpur M.P, 482007, India \\ ${ }^{2}$ Rajmata VijayarajeScindia Krishi Vishwa Vidyalaya, Gwalior, 474002, India \\ ${ }^{3}$ JNKVV Jabalpur M.P 482007, India \\ *Corresponding author
}

\section{A B S T R A C T}

\begin{tabular}{|l|} 
Ke y w o r d s \\
IPM, Soybean \\
grower, Knowledge \\
and Adoption, Chi- \\
square test
\end{tabular}

The present study was conducted at Pandhana block of Khandwa district Madhya Pradesh. The finding of the research revealed that Integrated Pest Management practice by soybean growers. The out of total soybean growers $47.27 \%$ had low adoption level of integrated pest management practices and only $5.46 \%$ had high adoption level of integrated pest management practices. The study also indicated the association between various attributed of soybean growers like education, annual income, scientific orientation, attitude toward IPM, knowledge of IPM, mass media exposure, extension contact were found to be 0.05 level of significance with adoption of IPM practices, Whereas age, family size, family type, land holding, area under soybean had showed that non-significant association with adoption level of soybean growers, thus the study highlighted the high adoption of integrated pest management practices by soybean growers.

\section{Introduction}

Soybean (Glycine max L. Merril) is the world's most important seed legume, which contributes to twenty-five per cent of the global edible oil, about two-thirds of the world's protein concentrate for livestock feeding. Soyabean is native of east Asia, China is considered the place of origin of soybean. Soybean is cultivating in large quantities all over the world to obtain oil from its seeds. Soybean seeds contain 43 per cent protein and 20 per cent oil.

Soybeans are rich in protein and are therefore an important option to address the worldwide protein shortage. Soya milk is a by-product of soybean. curd, cheese and tofu are made from soya milk amongst soybean producing countries USA stands position first while 
India fifth. In India soybean is cultivated in about 120.327 lac hectares area and production is about 129.832 lac metric ton (Sopa 2013). Madhya Pradesh is recognized as soybean state in our country. In Madhya Pradesh, soybean is cultivated in about 108.834 lac hectares area with the production of 104.366 lac metric ton (Sopa, 2014) while in Khandwa district soybean is cultivated in 1.945 lac hectares area with the production of 2.400 lac metric tons (Sopa, 2013). The productivity of soybean is affected by many factors viz. crop genetics, resource managements and climatic factors.

The losses caused by weeds, insects, diseases are $75 \%, 15-20 \%, 10-15 \%$, respectively (James and Bittzer, 2011). Integrated Pest Management (IPM) approaches have been globally accepted for achieving sustainability in agriculture and maintaining the agro-ecosystem. It is more relevant due to a number of advantages like safe to environment, pesticide free food commodities, low input-based crop production. Integrated Pest Management, therefore emphasizes not only reduction in use of chemical pesticide and keeping the level of pest causing economic injury but also facilitates the use of cultural, physical, mechanical and biological method of pest control. Although, IPM is the best strategy in crop production programme, yet this practice could not reach to the farmers' field. therefore, a study was conducted with the following objectives for the study:

To find out the constraints perceived by soybean growers in adoption of Integrated Pest Management practices.

\section{Materials and Methods}

The study was conducted in Khandwa district of Madhya Pradesh. The Pandhana blocks of Khandwa district comprise of 102 villages, out of which, a list of soybean growing villages were prepared with the help of extension officials and five villages were selected on the basis of large area under soybean crop. There are seven blocks in Khandwa district, out of which Pandhana block was selected purposively for the study because area under soybean crop is highest but productivity is comparatively low as compared to other blocks of the district.

Soybean growers were selected by using proportionate random sampling method to make the total sample size 110 for the present study. the secondary data were collected from department of Agriculture, the respondent was asked to give opinion about the use of recommended soyabean growers practices (adoption) on three points continuums viz. complete, uncompleted and never and scores 2, 1 and 0 were assigned respectively.

Similarly, the constraints faced by the soybean growers, were also recorded on the two-point continuum namely Yes and No the data were analyzed using frequency, percentage, mean, chi-square test and association between dependent and independent variables.

\section{Results and Discussion}

The data regarding constraints in adoption of integrated pest management practices as reported by soybean growers is presented in table 4.30 reveals that large majority of the soybean growers faced the constraints i.e. improper technical knowledge about bioagent and bio-insecticide (95.45\%) followed by Improper technical knowledge about chemical insecticide (94.54\%), Improper knowledge about pheromone trap (89.09\%), Non availability of bio-insecticide $(88.18 \%)$, Insufficient fund to purchase useful agriculture inputs (84.54\%), Improper knowledge about light trap (82.72\%), Lack of knowledge about seed treatment $(81.81 \%)$, 
Improper knowledge about chemical fertilizer (74.54\%), Non availability of labours $(53.63 \%)$, Non availability of seed of resistant variety $(50.90 \%)$.

The above findings indicating that the majority of soybean growers faced problem in adoption of mechanical control and biological control. The major constraints perceived by soybean growers were improper technical knowledge about bio-agent and bio- insecticide, improper knowledge about chemical insecticide, improper knowledge about pheromone trap, non-availability of bioinsecticide, insufficient fund to purchase useful agriculture inputs, improper knowledge about light trap, lack of knowledge about seed treatment, improper knowledge about chemical fertilizer, non-availability of labours and non-availability of seed of resistant variety.

Table.1 Constraints perceived by soybean growers in adoption of integrated pest management practices $(\mathrm{N}=110)$

\begin{tabular}{|c|l|c|c|c|}
\hline S. No & \multicolumn{1}{|c|}{ Constraints } & \multicolumn{3}{|c|}{ Adoption } \\
\cline { 5 - 5 } & & Frequency & Percent & Rank \\
\hline $\mathbf{1}$ & $\begin{array}{l}\text { Improper technical knowledge about bio-agent } \\
\text { and bio-insecticide }\end{array}$ & 105 & 95.45 & I \\
\hline $\mathbf{2}$ & $\begin{array}{l}\text { Improper technical knowledge about chemical } \\
\text { insecticide }\end{array}$ & 104 & 94.54 & II \\
\hline $\mathbf{3}$ & Improper knowledge about pheromone trap & 98 & 89.09 & III \\
\hline $\mathbf{4}$ & Non availability of bio-insecticide & 97 & 88.18 & IV \\
\hline $\mathbf{5}$ & $\begin{array}{l}\text { Insufficient fund to purchase useful agriculture } \\
\text { inputs }\end{array}$ & 93 & 84.54 & V \\
\hline $\mathbf{6}$ & Improper knowledge about light trap & 91 & 82.72 & VI \\
\hline $\mathbf{7}$ & Lack of knowledge about seed treatment & 90 & 81.81 & VII \\
\hline $\mathbf{8}$ & Improper knowledge about chemical fertilizer & 82 & 74.54 & VIII \\
\hline $\mathbf{9}$ & Non availability of labours & 56 & 53.63 & IX \\
\hline $\mathbf{1 0}$ & Non availability of seed of resistant variety & 50.90 & X \\
\hline
\end{tabular}

The study revealed that higher percentage of the soybean grower were belonged to middle age group, acquired primary school education, having medium family size, nuclear family type, having medium annual income, medium size of land holding, and medium size of land holding area under soybean crop, and low farm power. In case of psychological attributes, most of the soybean growers had medium and high level of economic motivation, medium scientific orientation, had having medium attitude towards IPM practices and medium knowledge towards IPM Practices.
In case of communicational attributes higher percentages of soybean growers were having low extension contact, and majority had medium mass-media exposure.

\section{References}

Alexander M. 1997. Pulse crop. Oxford and IDH publishing Co. Pvt. Ltd, pp-55. James H and Bitzer J. 2011. Production in kentucky part iv, weed, disease and insect control AGR-131 issued 4-88.

Mandloi RS. 2007. A comparative study on 
adoption of soybean production technology in high and low productive block of Dhar district (M.P.). M.Sc. (Ag.) Thesis, JNKVV, Jabalpur.

Nagle S. 2009. Impact of Front-Line Demonstration on knowledge and adoption level of wheat growers in Indore block of Indore district of M.P. M.Sc. (Ag.) thesis, JNKVV, Jabalpur.

Pande AK, Panwar MP and Sanoria YC. 1998. Adoption of soybean production technology among farmers. Madhya Journal of Ext. Edu. 1(1): 38-42

Patidar M. 2011. A study on adoption of IPM practices by soybean growers in Tikamgarh district of Madhya
Pradesh. M.Sc. (Ag.) Thesis (Unpublished), JNKVV, Jabalpur.

Sharma Rohit 2007. A study of knowledge and adoption behaviour of soybean growers in Sehore district of M.P. M.Sc. (Ag.) Thesis, JNKVV, Jabalpur. Soybean Production Association. 2013. Area and production of soybean in IndiaKharif 2013 survey conducted by Indore with effect from September 1527.

Verma L. 2009. "A study on adoption of integrated pest management practices by the cotton growers in Khandwa District (M.P.)" M.Sc. (Ag.) Thesis, J.N.K.V.V., Jabalpur

\section{How to cite this article:}

Shivpal Singh, G. Bihare, P. Kumar, G. Uikey and Agrawals, K. 2020. A Critical Study on (IPM) Integrated Pest Management and its Adoption among the Soybean Growing Farmers of Khandwa District of M.P, India. Int.J.Curr.Microbiol.App.Sci. 9(05): 2339-2342.

doi: https://doi.org/10.20546/ijcmas.2020.905.266 